\title{
The Influence of Social Media on Academic Performance of Taraba State University Undergraduate Students
}

\author{
Apuke Destiny Oberiri, Taraba State University, Nigeria
}

\begin{abstract}
This study examined the influence of social media on students' academic performance. A study of Taraba State University students. Quantitative survey method was adopted for the study. The population consists of 5000 undergraduate students. The study made use of Taro Yame's formula to sample 100 students. Questionnaires were employed as the instrument for data collection. The questionnaire was administered to 100 randomly selected students. The entire questionnaires administered were duly filled and retrieved given a high response rate of $100 \%$. The gamut of this study is on the uses and gratification theory. Data collected were coded and analysed on SPSS version 22 and presented in tables. Findings revealed that students of Taraba State University have access to the internet and that they do so through different mediums such as smart phones, tablets and computers. The study also postulate that students who spend more time on social media are likely to perform poorly in their academic activities than those who do not. The study recommends that students should decrease their introduction to social media and give careful consideration to their studies. Students, particularly those ready to record gigantic scholarly achievement should guard themselves against the successive utilization of social media.
\end{abstract}

Keywords: Social media, Academic performance, Students, Taraba State University 


\section{Background of the Study}

There is enormous celebration on the planet today because of the imminent and change in the communication pattern which has helped the scope of communication by means of Information and communication technology (ICTs). Ufuophu and Ayobami (2012:129) observe that the ICTs include internet, satellite, cable data transmission and computer assisted equipment. Social network is a social structure made up of individuals or organizations called "nodes", which are tied (connected) by one or more specific types of interdependency, such as friendship, kinship, common interest, financial exchange, dislike, sexual relationships or relationships of beliefs, knowledge or prestige.

Social media has emerged to be one of the most vital communication means. It exist so as to ease communication among people regardless of the expanse, making it open to people to easily share information, files and pictures and videos, create blogs and send messages, and conduct real-time conversations. These systems are referred to as social, simply because they allow communication with friends, course mates, teachers, project supervisors, lecturers etc so easily and effectively. Social media which are a form of electronic communication that has become the highest activity on the internet.

According to Kim and Kim, (2010) "Social media are the emerging digital communication channels which create a user oriented information sharing ground where any people can generate or subscribe information content as both information provider and consumer". Buettner, (2016) sees social media as "computer mediated tools that allow people or companies to create, share exchange information, career interest, ideas, pictures/ virtual communities and networks"

By suggestion, through Social media, individuals can with no much of a stretch trade profitable information which can enhance their profession interest, thoughts and so on. It additionally helps in sending pictorial outlines of thoughts. Andreas and Micheal (2010) asserts that "social media is a group of internet-based applications that build on the ideological and technological foundations of web 2.0 and that allow the creation and exchange of user generated content”. Kietzmann and Hermkens (2011) elaborates on this, stating that "social media depends on Mobile and Web-based technologies to create highly interactive platforms through which individuals and communities share, co-create, discuss, 
and modify user-generated content. They introduce substantial land pervasive changes to communications between communities and individuals".

In contribution, Ganiyu, and Akinreti, (2011) assert that "the emergence of social media has increase interactivity among people, making them to be producers and consumers of information in a simultaneous manner". Social media such as Facebook, Twitter, 2go etc have brought tremendous improvement in the communication system which enhances learning, it has provided different entertainment functions which serve as a tool for social change and fast exchange of information. With the aid of the internet students can form their own page, access to news and lectures notes via email sent to him/her by a lecturer.

An additional benefit of social technologies provided on the internet is that they are frequently free or require marginal investment, eliminating a potential barrier to adoption (Brown, 2010).

There has been various overview and opinions which recognized four major advantages of social media use in higher education. These include, enhancing relationship, improving learning motivation, offering personalized course material, and developing collaborative abilities .This means that social networking activities have the possibility of enhancing student contact and is used to improve their participation in class, particularly where introverted students are involved. "Students can function in online group learning, with less or no anxiety of needing to raise questions before peers at school" (Wheeler, Yeomans, and Wheeler, 2008). Against this backdrop this study examined the influence social media have on student's academic performance with specific reference to Taraba State University students.

\section{Statement of the Problem}

Since the initiation of social media sites in the 1990s, it is understood that in many part of the world the academic performance of students is facing a lot of neglect and challenges. There is a divergence, interruption and alienated attention between social networking activities and their academic work. It is pragmatic that students dedicate more attention to social media than they do to their studies. Asemah, Okpanachi and Edegoh, (2013) describe this situation stating that "it is a common sight to see a youth chatting in sensitive 
and highly organized places like church, mosque and lecture venues. Some are so carried away that even as they are walking along the high way, they keep chatting”.

\section{Research Questions}

Based on the objectives, the study examined the following research questions:

(i) Do you use social media networks?

(ii) What are the social media networks that you are more exposed to?

(iii) What is the influence of social media on your academic performance?

\section{Explicating literature/empirical studies}

Adegboji and Toyo (2006) in their study on the impact of social media on research, reported that social media contributed significantly to the ease of research through materials online. It is commonly believed that researchers and students in Nigerian Higher education institution are battling the problem of Inadequate and out-of-date materials. The only way to pursue knowledge is through research and the Internet as well as social media which sprang from the internet is having a profound impact on the research process and dissemination of Information. (Kamba 2008).

Therefore to ascertain the effects/influence of social media on academic performance, the researcher reviewed various empirical studies by different scholars who have written on social media influences on students' academic performance as follows: Sofela, T. (2012). The Effect of Social Media on Students. (A paper presented in Craft Magazine October 23 2012).

According to the researcher, the popularity of social media has grown expediently. The social networking site such as face book, MySpace, $2 \mathrm{go}$ and BB chat allows social interaction among students. The study examined the positive effect of such site on youths. It said, gone are those days when events happen and it stays a while before people begin to hear about it. But now, through social media, events and news are now known within splits second after they are shared. It offers youths a channel for entertainment, communication, and meeting friends and those you've not seen for a long time. The study also analyzed the negative consequences of such site. Despite the positive gain, it comes with the negative impact of it. It was before now used by students for research but most students abandoned their home work to chat with friends. 
However, the study reviewed and the present study emphasized on the impact of social media on students, stressing on the positive impact in the student's academic performance as well as the negative influence. The study emphasized the need for students to create a balance between social media and their academics to prevent setbacks.

But the reviewed study failed to throw more light on the negative influence of social media on the academic performance of students. The present study therefore analyzed both sides of the coin giving the students the opportunity to choose what impact they want the social media to play in their academics. Seyi, O. (2012), Social Media and Nigeria Youth Burden.(A paper presented in Blue Print Newspaper December 17 2012). This study stressed on the negative effect of giving too much time and undue attention to online socialization to the detriment of academics.

According to the researcher, the 21 st century brought with it the advent of the new media with its fast tracking means of sending and receiving information via internet in our contemporary society, the new media has gained popularity as its been used for entertainment, networking and academics. The study noted that, the social media was given a boost as a result of ideas from youths.

The study criticized seriously the obsessive attitude of Nigeria youths towards social media. It pointed out that the rate at which youths devote their quality time in chit chatting, calls for urgent attention. Some guys now find social media soothing to propagate harmful schemes. The study however, traced the incessant incidents of murders and gang-rapping of girls by guys whom they interacted with through social media. It gave an instance with the case of a girl; Cynthia was gang-raped when she went visiting a friend she met through social networking site (2go), and whose nude pictures were displayed on the net by the perpetrators. Another case in question is that of a girl who paid a visit to her face book friend in Lagos and base on their arrangement; she logged and waited for his arrival. On his arrival, he asked her for sex and she refused and out of annoyance, he plugged off one of her eyes and sliced her nipple and he escaped. Every effort made to get him proved abortive because he had a fake identity. 
The study also observed that some students are always busy pinging and 2going while lectures are on. Time ought to be channeled towards learning, academic research and innovations have been wasted by the passion of meeting friends and discussing trivial issues, hence, most students' academic suffer setbacks as a result of distraction. The reviewed study and present study were both centered on the use of social media by students. They both emphasized on the statement of the problem suggesting the need for more time to be channeled to academics to prevent setback that might be caused by the use of social media.

The reviewed study was not based on any theory. It also failed to provide possible solutions for the way forward in solving issues relating to student's academic performance and social media. The present study was based on diffusion of innovation theory and uses and gratification theory, thereby giving it a firm foundation. Asogwa, Ojih and Onoja (2012) Use of Social networking sites and Academic Performance among Students of Selected Tertiary Institutions in Kogi State (International Journal of African and Asian Studies)

The study assessed the use of Social networking sites and Academic Performance among Students of Tertiary Institutions in Kogi State with a focus on Facebook, by looking into the specific use of facebook among students of some selected higher institutions in Kogi state (KSU, FPI and FCE; its level of usage; and also to identify the possible effects of facebook on their academic performance. Anchored on uses and gratifications theory, the study employed survey research method and relied on questionnaire as instrument for the collection of primary data. A sample of 384 students was selected from the students' total population of 23,474 using fitcher formula.

Through multi-stage sampling technique, the questionnaire was proportionately administered in each of the schools on the randomly selected students. The data were quantitatively analyzed using tables showing frequencies and simple percentages. Results revealed amongst other things that, Students use facebook primarily to escape from boredom, for communication; make new friends; update status; chats; post/comment on photos; and admonition among others. Finding also reveals that majority of the students hardly ever visit the site during class period, studying hours or miss classes because of facebook; that facebook usage does not have negative effect on the students' academic performance (except on their spoken and written communication). The study concludes that the utilization of social media 
by students of tertiary institutions in Kogi state portends both beneficial results of the uses and gratifications highlighted in this study which show that facebook has a significant positive influence on the students limited danger to the academic performance of students and recommends among other things that students should be encouraged to adequately utilize the potentials of facebook for academic excellence and also that, lecturers should look out for and completely discourage the use of facebook and other Social networking sites gadgets during classes

Asemah, E.S and Edegoh, L.O.N. (2013). Influence of Social Media on the Academic Performance of the Undergraduate Students of Kogi State University, Anyigba, Nigeria. (Journal of Research on Humanities and Social Sciences) The paper examined the influence of social media on the academic performance of the undergraduate students of Kogi State University. The rationale behind the study is to find out whether the exposure of the students to social media has effect on their academic performance. The paper was anchored on two theories; namely: social information processing theory and media equation theory. The survey research method was adopted, employing the questionnaire as an instrument of data collection. The findings show that undergraduate students of Kogi State University, Anyigba, Nigeria, have access to social media and that their exposure to social media is to a very great extent. Findings also show that exposure to social media has effect on the students and that the effect is negative. Findings also show that facebook is the most used social media by undergraduate students of Kogi State University. Based on the findings, the paper concludes that exposure to social media by the undergraduate students of Kogi State University has negative effect on their academic performance. To this end, the paper recommends that the students should pay minimal attention to social media and focus more on their academic activities.

Ifeanyi-obi, Olatunji, and Akpala, (2014) Perceived Effects of Facebook on Academic Activities of Agricultural Students in University Of Port Harcourt (IOSR Journal of Mobile Computing \& Application). The study assessed the perceived effects of Facebook on academic activities of Agricultural students in the University of Port Harcourt, Nigeria. Data were collected with the use of structured questionnaire from randomly selected 80 agriculture students and analyzed using descriptive statistical tools namely frequency, mean and percentages. Result shows that $64 \%$ of the agriculture students were females and fall mostly 
(87.4\%) within the age brackets of 21-30years. Facebook (94\%), blackberry messenger (90\%) and Whatsapp (72.5\%) were found to be the most frequently used social media by the students. Result on frequency of use of facebook shows that students visit facebook page mainly once in three days (60\%). Majority (60\%) spends an hour or less on Facebook daily while the major action mostly performed is chatting (36.25\%). The agriculture students agree that facilitation of networking with other agric students $($ Mean $=3.00)$, collaboration with other students (Mean = 3.00 and ease of information flow ( Mean = 3.41) were the major effects of facebook on their academic activities. The overall rating of effect of facebook shows that facebook affect the academic activities of agriculture students positively (67\%). Based on the findings of the study, it was recommended that the positive effect of facebook among students should be encouraged while the excessive use of facebook for recreational purposes should be discouraged.

Ndaku (2013) Impact of social media on students' academic performance -A study of students of University of Abuja. (An undergraduate project submitted to Department of mass communication management and social sciences Caritas University. The aim of the study was to analyze the impact of social media on the student's academic performance [A study of students of University of Abuja]. To achieve this, the survey research method was used. Subjects were drawn from the University of Abuja, using the simple random sampling technique and purposive sampling. Four research questions guided the study. Research findings showed that a great number of students in University of Abuja, had access to the internet. To this end, the researcher recommended that sites should be created for educational purposes as well. This is to create a balance between social networking and academic activities of students to avoid setbacks in the academic performance of the students.

From the above studies it could be articulated that Modern Technology in correspondence undoubtedly has transformed the whole world into a "Worldwide Village". Be that as it may, modernization like two sides of a coin, carry with it both the negative and positive sides.

This implies that although social media is a very good tool that improve educational upbringing of students if used appropriately, it also have negative aspect if a student over indulge themselves to it. Social networking sites are considered to play an active role in younger generation's daily lives (Lenhart, 2009), as most of the active users are students of 
tertiary institutions. No wonder, Oblinger and Oblinger (2005:12) called them 'the most wired and connected generation in human history', 'Digital Natives', and 'the Net Generation'. Against this backdrop, Social networking sites have become excellent tools for education and can be used socially and collaboratively between learners and teachers as well as amongst students.

Asabere (2012: 462-470) notes that "current ICT trends are providing accessibility to online services such as social networks and these enable collaboration amongst students and contribute a lot to social learning activities. Students of tertiary institutions in Nigeria are keying into the limitless opportunities". The rapid growth of this technology has improved and enabled collaborative and learning activities especially because of its high level of interactivity, accessibility and affordability.

However, exposure and use of these networks tend to have both positive and negative implications on the student. Oye, Helou and Rahim (2012:25) buttress this in their assertion emanating from their findings that "as a result of more time being dedicated to the use of Social networking sites for non-academic usage and less time to academic usage by students, it tells considerably on what becomes their academic output". In view of this, the use of Social networking sites has raised dust among researchers. Some see it as distraction to learning for the student as it involves multitasking, while others attest to the potentials of Social networking sites for learning. There are also those who argue that young adult learners view and use Social networking sites as a platform for socializing more than learning.

\section{Theoretical framework}

\section{Uses and Gratification Theory}

Use and gratification was developed in 1974 by Katz, Blumler and Gurevitch (Wimmer \& Dominick 2011:294). Basically, the theory places more emphasis on "what people do with media" rather than "what media do to people" (Katz, 1959 cited in Idakwo, (2011:24). Uses and Gratifications theory is the study of the gratifications or benefits that attract and hold audiences to various types of media and the types of content that satisfy their social and psychological needs. 
Social networking sites as new media of communication also lends itself to uses and gratifications approach, in part due to its interactive nature (Grant, 2005:627). Uses and gratifications research has typically focused on how media are used to satisfy cognitive and affective needs involving personal needs and entertainment needs (Rubin, 2002:46). This hypothesis specifically puts power in the hands of the crowd. Instead of expecting that media messages have immediate, uniform impacts on the individuals who devour them, the Uses and Gratifications point of view suggests that beneficiaries make planned, purposeful choices about the media messages they open themselves to and at what recurrence taking into account individual needs and cravings independent of its impact on them-positive or negative. Relating this theory to this current study, it shows that students use Social networking sites like facebook, whatsapp, 2go, twitter etc just to satisfy their needs- which may either be physical or psychological- irrespective of the direction of its influence on their academic performance. Besides, it offers explanations to suggest that students use this site for varying reasons. In other words, users select media based on how well each one helps them meet specific needs or goals. Hence, this study tries to find out how this uses and gratification derived from the use of social media by students of Taraba state University impacts on their academic performances.

\section{Materials and Methods}

This study made use of quantitative survey research design. The study area is Taraba State University, Jalingo. The population of this study is the entire students of Taraba State University, Jalingo who are about 5000 (Source: www.tsuj.edu.ng, 2016).

To determine the sample of this study the Taro Yamane's formula will be adopted as follows: $\mathrm{N}=$ $\mathrm{N}$

$$
1+N(e)^{2}
$$

Where: $\mathrm{N}=$ sample size sought

$\mathrm{e}=$ Level of error $(0.10)^{2}$

$\mathrm{N}=$ Population size 5000

$\mathrm{N}=\quad 5000$

$$
1+5000(0.10)^{2}
$$

$\mathrm{N}=$ 


$$
1+5000 \overline{(0.01)}
$$

$\mathrm{N}=\quad 5000$

51

$\mathrm{N}=$

100

Therefore, the sample for this study is 100 respondents who were randomly selected from Taraba State University Jalingo. The sampling technique adopted for this study is simple random sampling technique in which each member of the sample is given an equal chance of being selected (Yates, David and Daren 2008). The study employed questionnaire in gathering the data. The data collected were coded in SPSS version 22 and analysed using descriptive statistics with reference to devices such as tables, frequency counts and simple percentages.

\section{Data Analysis}

\section{Information on the Respondents}

Findings from the data gathered revealed that $60(60 \%)$ out of the 100 respondents are female and $40(40 \%)$ are male and $45(45 \%)$ out of the 100 respondents fall under the ages of $18-24,30(30 \%)$ out of the 100 respondents fall under the ages of 25-31, while 15 (15\%) fall under the ages of 32-38 and 10(10\%) fall under the ages of 39 and above. This implies that most of the respondents fall under the ages of 23-25.

\section{Explicating Research Question One: Do you use social media networks?}

To answer this question, items 3,4 and 6 was used from the questionnaire.

Table 1 Respondents access to the internet. Do you have access to the internet?

\begin{tabular}{|l|l|l|}
\hline Responses & Frequency & Percentage \\
\hline (a) Yes & 100 & 100 \\
\hline (b) No & 0 & $0 \%$ \\
\hline Total & $\mathbf{1 0 0}$ & $\mathbf{1 0 0}$ \\
\hline
\end{tabular}

Source: Field survey, Taraba State University, 2016. 
Table 1 above reveals that all the respondents have access to the internet. The question now is what medium they use to access the internet. The next question answers the various mediums used by the respondents to access the internet.

Table 2 Medium of accessing the internet. Which of the following medium do you use to access the internet?

\begin{tabular}{|l|l|l|}
\hline Responses & Frequency & Percentage \\
\hline (a) Computer & 25 & $25 \%$ \\
\hline (b) Smart Phones & 65 & $0 \%$ \\
\hline (c) Tablet & 10 & $10 \%$ \\
\hline Total & $\mathbf{1 0 0}$ & $\mathbf{1 0 0}$ \\
\hline
\end{tabular}

Source: Field survey, Taraba State University, 2016.

Table 2 above ascertained the medium used by the respondents in accessing the internet. The findings reveals that majority of the respondents $65(65 \%)$ make use of smart phones to access the internet, while 25 (22\%) make us of computer, whereas, only $10(10 \%)$ make use of tablet to access the internet.

Table 3 Social media account of respondents. which of the social networking sites do you have an account with?.

\begin{tabular}{|l|l|l|}
\hline Responses & Frequency & Percentage \\
\hline (a) 2go & 5 & $25 \%$ \\
\hline (b) BB chat & 15 & $15 \%$ \\
\hline (c) Face book & 50 & $50 \%$ \\
\hline (d) My space & - & \\
\hline (e) Whatsapp & 30 & $30 \%$ \\
\hline (f) others specify & - & \\
\hline Total & $\mathbf{1 0 0}$ & $\mathbf{1 0 0}$ \\
\hline
\end{tabular}

Source: Field survey, Taraba State University, 2016.

Table 3 above examined the social networking sites the respondents have account with. Findings reveal that a reasonable amount of the respondents $50(50 \%)$ have an account with 
Face-book, while 30 (30\%) have an account with Whatsapp, 15 (15\%) have an account with BB chat, and only 5 (5\%) out of the 100 respondents have an account with 2 go. This findings implies that majority of the respondents have an account with Face-book rather than any other networking sites.

\section{Research Question Two: What are the social media networks that you are more exposed to?}

Items 7, 9, 10, 11 from the questionnaire answered research question two.

Table 4 Social media mostly exposed to by the respondents. Which Social Media Network are you mostly exposed to?

\begin{tabular}{|l|l|l|}
\hline Responses & Frequency & Percentage \\
\hline (a) 2go & 5 & $25 \%$ \\
\hline (b) BB chat & 10 & $10 \%$ \\
\hline (c) Face book & 60 & $60 \%$ \\
\hline (d) My space & - & \\
\hline (e) Whatsapp & 25 & $25 \%$ \\
\hline (f) others specify & - & \\
\hline Total & $\mathbf{1 0 0}$ & $\mathbf{1 0 0}$ \\
\hline
\end{tabular}

Source: Field survey, Taraba State University, 2016.

Table 4 above examined the type of social media the respondents are mostly exposed to. Findings show that majority of the respondents 60(60\%) are more exposed to Face-book than any other networking site, while $25(25 \%)$ agreed to Whatsapp as the most exposed networking site to them, while $10(10 \%)$ out of the 100 respondents are more exposed to BB chat, whereas, only $5(5 \%)$ are exposed exposed to 2 go. This implies that most of the respondents are more exposed to facebook and Whatsapp than any other form of networking sites. 
Table 5 Frequency of respondents surfing the internet : How often do you go online?

\begin{tabular}{|l|l|l|}
\hline Responses & Frequency & Percentage \\
\hline (a) Very often & 75 & $75 \%$ \\
\hline (b) Often & 15 & $15 \%$ \\
\hline (c) Not very often & 5 & $5 \%$ \\
\hline (d) Not often & 5 & $5 \%$ \\
\hline Total & $\mathbf{1 0 0}$ & $\mathbf{1 0 0}$ \\
\hline
\end{tabular}

Source: Field survey, Taraba State University, 2016.

Table 5 above seek to ascertain the frequency of respondents surfing the internet. Findings revealed that majority of the respondents $75(75 \%)$ agreed that they surf the internet very often, $15(15 \%)$ surf the internet often, while $5(5 \%)$ go online not very often and $5(5 \%)$ not often. This implies that, most of the respondents go online very often. That is, there is high frequency of respondents going online.

Table 6 Hours of respondents going online. How much time do you spend online daily?

\begin{tabular}{|l|l|l|}
\hline Responses & Frequency & Percentage \\
\hline (a) 6 hours and above & 15 & $15 \%$ \\
\hline (b) 4-5 hours & 65 & $65 \%$ \\
\hline (c) 3-4 hours & 10 & $10 \%$ \\
\hline (d) 2-3 hours & 5 & $5 \%$ \\
\hline (e) 1 hour or less & 5 & 55 \\
\hline Total & $\mathbf{1 0 0}$ & $\mathbf{1 0 0}$ \\
\hline
\end{tabular}

Source: Field survey, Taraba State University, 2016.

Table 6 above reveals respondents time spent daily online. Majority of the respondents 65 (65\%) spend 4-5 hours surfing the internet, 15(15\%) spend 6 hours and above online daily, $10(10 \%)$ spent 3-4 hours, $5(5 \%)$ spend 2-3 hours, while 5(5\%) spend only 1 hour or less online. This implies that, most of the respondents spend a lot of time online. 
Table 7 Actions respondents do most on social media. Which of the action do you do most on social media?

\begin{tabular}{|l|l|l|}
\hline Responses & Frequency & Percentage \\
\hline (a) Academic activities & 15 & $15 \%$ \\
\hline (b) Sports and news & 5 & $5 \%$ \\
\hline (c) Entertainment & 10 & $10 \%$ \\
\hline (d) Chatting & 70 & $70 \%$ \\
\hline (e) Others & - & - \\
\hline Total & $\mathbf{1 0 0}$ & $\mathbf{1 0 0}$ \\
\hline
\end{tabular}

Source: Field survey, Taraba State University, 2016.

Table 7 explore the various actions carried out by the respondents on social media. Findings revealed that majority of the respondents $70(70 \%)$ prefer chatting to other form of internet surfing, $15(15 \%)$ agreed to using social media for academic purposes, 10(10\%) concurred to using social media for entertainment purposes while only $5(5 \%)$ out of the respondents make use of social media for sports and news. This implies that, most of the respondents chat, negating academic pursuits.

Research Question Three: What is the influence of social media on your academic performance?

Items 13-16 from the questionnaire answered research question three.

Table 8 Influence of social media on students' academic performance:

\begin{tabular}{|l|l|l|l|l|l|l|}
\hline $\begin{array}{l}\text { Item } \\
\text { S }\end{array}$ & Responses SA & A & UD & D & SD \\
\hline $\mathbf{1}$ & $\begin{array}{l}\text { Taraba State University undergraduate } \\
\text { students spend more time on social } \\
\text { media than reading their books }\end{array}$ & $70(70 \%)$ & $15(15 \%)$ & - & $10(10 \%)$ & $5(5 \%)$ \\
\hline $\mathbf{2}$ & $\begin{array}{l}\text { Students now rely on social media to } \\
\text { do their assignments without } \\
\text { consulting other sources }\end{array}$ & $5(5 \%)$ & $60(60 \%)$ & $5(5 \%)$ & $25(25 \%)$ & $5(5 \%)$ \\
\hline
\end{tabular}




\begin{tabular}{|c|c|c|c|c|c|c|}
\hline 3 & $\begin{array}{l}\text { Students' exposure to social media } \\
\text { have effect on their academic } \\
\text { performance }\end{array}$ & $65(65 \%)$ & $15(15 \%)$ & $5(5 \%)$ & $10(10 \%)$ & $5(5 \%)$ \\
\hline 4 & $\begin{array}{l}\text { The influence of social media on the } \\
\text { academic performance of students is } \\
\text { negative }\end{array}$ & $75(75 \%)$ & $10(10 \%)$ & - & $10(10 \%)$ & $5(5 \%)$ \\
\hline 5 & $\begin{array}{l}\text { Students who spend more time on } \\
\text { social media are likely to perform } \\
\text { poorly in their academic activities than } \\
\text { those who do not. }\end{array}$ & $80(80 \%)$ & $7(7 \%)$ & $5(5 \%)$ & $3(3 \%)$ & $5(5 \%)$ \\
\hline
\end{tabular}

Source: Field survey, Taraba State University, 2016.

Table 8 above seek to find out the influence social media have on students academic performance.

Items 1 from the table above seek to find out if Taraba State University students spend more time on social media than reading their books. 70 (70\%) out of the 100 respondents strongly agreed that Taraba State University students spend more time on social media than reading their books, $15(15 \%)$ agreed to the same assertion, on the other hand, 10 (10\%) disagreed that Taraba State University students spend more time on social media than reading their books while $5(5 \%)$ strongly disagreed.

Items 2 from the table sought to find out if students now rely on social media to do their assignments without consulting other sources. 5(5\%) strongly agreed that students now rely on social media to do their assignments without consulting other sources. 60 (60\%) agreed that students now rely on social media to do their assignments without consulting other sources. $25(25 \%)$ disagreed that students now rely on social media to do their assignments without consulting other sources, $5(5 \%)$ strongly disagreed while $5(5 \%)$ remained undecided as to whether students now rely on social media to do their assignments without consulting other sources. 
Items 3 examined whether Students' exposure to social media have effect on their academic performance. Majority of the respondents $65(65 \%)$ strongly agreed that students' exposure to social media have effect on their academic performance, $15(15 \%)$ agreed that students' exposure to social media have effect on their academic performance, $10(10 \%)$ disagreed that Students' exposure to social media have effect on their academic performance, while $5(5 \%)$ strongly disagreed that students' exposure to social media have effect on their academic performance and $5(5 \%)$ remained undecided.

Items 4 seek to ascertain if the influence of social media on the academic performance of students is negative. Majority of the respondents $75(75 \%)$ strongly agreed that the influence of social media on the academic performance of students is negative, $10(10 \%)$ agreed that the influence of social media on the academic performance of students is negative, $10(10 \%)$ disagreed that the influence of social media on the academic performance of students is negative, while $5(5 \%)$ strongly disagreed that the influence of social media on the academic performance of students is negative. This implies that to a very large extent, social media have negative influence on students academic performance.

Items 5 sought to know whether students who spend more time on social media are likely to perform poorly in their academic activities than those who do not. Most of the respondents 80 $(80 \%)$ strongly agreed that students who spend more time on social media are likely to perform poorly in their academic activities than those who do not, 7(7\%) agreed that students who spend more time on social media are likely to perform poorly in their academic activities than those who do not, 3 (3\%) disagreed that students who spend more time on social media are likely to perform poorly in their academic activities than those who do not, 5 strongly disagreed that students who spend more time on social media are likely to perform poorly in their academic activities than those who do not. On the contrary, $5(5 \%)$ maintained neutrality as to whether students who spend more time on social media are likely to perform poorly in their academic activities than those who do not.

Base on the table above, one could deduce that social media have influence on student's academic performance and that influence is negative. This implies that, the continuous addiction to social media could deter students from studying their books as they will glue themselves to it rather than their books. 


\section{Discussions of Major Findings}

In this section, the data collected from survey on the topic "The influence of Social Media on the academic performance of students will be discussed in details relating it to other scholars work. The study reveals that all the respondents have access to the internet and that they do so through different mediums such as smart phones, tablets and computers.

Findings also reveal that smart phones are the most popular means of accessing the internet by students. These devices are portable and allow students to carry it along at any given time.

The study examined the various social media networking sites that respondents have an account with and found out that Facebook and Watsapp are the most conversant social media among students of Taraba State University. They would prefer to open account with Facebook and Whatsapp than any other social media form. Therefore, majority of the respondents are more exposed to Face-book and Whatsapp than any other networking sites. That is, students of Taraba State University prefer chatting on Facebook and Whatsapp. These findings is in line with Asemah, and Edegoh, (2013) findings that shows that facebook is the most used social media by undergraduate students of Kogi State University.

This study also reveal that majority of students of Taraba State University spend at least 4-5 hours or so daily surfing the internet. This shows that most of them go online as revealed in the study. These findings are in line with Seyi, (2012), study which criticized seriously the obsessive attitude of Nigeria youths towards social media. It pointed out that the rate at which youths devote their quality time in chatting, calls for urgent attention.

The study further examine the various actions taken by students on social media and found out that most students prefer to chat than do any other thing on social media. This finding concurs with Seyi, (2012) who observed that "some students are always busy pinging and 2going while lectures are on rather than concentrating and this affects their academic pursuit".

Findings of this study reveal that Taraba State University students spend more time on social media than reading their books, this makes them rely on social media to do their assignments without consulting other sources. The study also revealed that students' exposure to social 
media has effect on their academic performance and that effect is negative. Further findings revealed in this study is that students who spend more time on social media are likely to perform poorly in their academic activities than those who do not.

\section{Summary/Conclusion}

There is gigantic festival on the planet today because of the coming and change in the communication innovation which has helped the extent of communication by means of Information and communication technology (ICTs). In this manner, this study determine the impact of online networking on undergraduate scholastic execution with special reference to Taraba state University undergraduate. Discoveries demonstrated that an extraordinary number of understudruates in the Taraba state university know about online networking and have entry to different interpersonal interaction locales. It is the perspective of this paper that undergraduate who invest more energy in online networking are liable to perform inadequately in their scholarly exercises than the individuals who don't, because of an extraordinary number of times spent on long range informal communication exercises, the scholastic execution of undergraduates endure misfortunes which could prompt poor execution in their studies.

\section{Recommendations}

In view of the discoveries of this study, the accompanying suggestions can be made

i The government should consider the possibility of evolving a policy on teenagers' exposure to social media.

ii. Students should decrease their introduction to social media and give careful consideration to their studies.

iii. Students, particularly those ready to record gigantic scholarly achievement should guard themselves against the successive utilization of social media.

iv. The government, schools and other well to do people should empower hardwork by remunerating effective students through grant plans and different impetuses. 


\section{References}

Adegboji, O.B., \& Toyo, O.D (2006). The Impact of the Internet on research: The experience of Delta State University, Abraka, Nigeria. Library Philosophy and Practice 8

Andreas K M., Micheal, H (2010) Users of the world, unite! The challenges and opportunities of social media. Business Horizons 53 (1) 661 .

Asemah, E.S and Edegoh, L.O.N. (2013). Influence of Social Media on the Academic Performance of the Undergraduate Students of Kogi State University, Anyigba, Nigeria. Journal of Research on Humanities and Social Sciences Vol .3(12)

Asogwa C. E, Ojih, E. U and Onoja, B. I (2012) 'Use of Social networking sites and Academic Performance among Students of Selected Tertiary Institutions in Kogi State International Journal of African and Asian Studies. Vol 6.

Brown, S. (2010). From VLEs to learning webs: the implications of Web 2.0 for learning and Ganiyu, M., \& Akinreti, Q. (2011).Secrets of Online and Multimedia Journalism: A manual for Online and Multimedia Journalism practice in Africa. Ibadan: Emgee Publishers Ltd.

Buettner, R. (2016) Getting a Job via Career oriented Social networking sites: The weakness of Ties. $49^{\text {th }}$ Annual International Conference on systems sciences. Kauai, Hawaii: IEEEE. Doi:10.13140/RG. 2.1.3249.2241

Grant, I. (2005). Young; peoples' relationship with online marketing practices: an intrusion too far? Journal of Marketing Management, 21(5/6), 607-623.

Kamba, M.A (2008). The changing role of resources in Nigeria: The Internet as an alternative future to modernity. Library Philosophy and Practice.

Ifeanyi-obi C.C, Olatunji S.O, and Akpala, J (2014). Perceived Effects of Facebook on Academic Activities of Agricultural Students in University Of Port Harcourt . IOSR Journal of Mobile Computing \& Application.

Idakwo, L. (2011) The Use of Social Media among Nigerian Youths. Retrieved 9/7/2012 from: http://www.slideshare.net/goldlami/the-use-of-social-media- among-Nigerianyouths

Kietzmann, H., Jan; Kristopher Hermkens (2011). Social Media” Get serious. Understanding the functional building blocks of social media. Business Horizons 54: 241-251

Kim, Y., Kim, M. and Kim, K. (2010). Factors influencing the adoption of social media in 
Ndaku, A.J (2013). Impact of social media on students' academic performance -A study of students of University of Abuja. (An undergraduate project submitted to Department of mass communication management and social sciences Caritas University

Rubin, A. (2002). Media Uses and Effects: A Uses-and-Gratifications Perspective. In J. Bryant \& D. Zillmann (Eds.); Media Effects: Advances in Theory and Research (pp.417-436). New Jersey: Lawrence Erlbaum Associates, Inc.

Seyi, O. (2012), Social Media and Nigeria Youth Burden. A paper presented in Blue Print Newspaper December 172012.

Sofela, T. (2012). The Effect of Social Media on Students. A paper presented in Craft Magazine October 23 2012).

Ufuophu, E and Agobami, O. (2012). Usage of information and communication technologies and job motivation among newspaper workers in Nigeria. Journal of Communication and Media Research. Vol.4. (1).

Wheeler, S., Yeomans, P., \& Wheeler, D. (2008). The good, the bad and the wiki: Evaluating student-generated content for collaborative learning. British Journal of Educational Technology, 39(6), 987-995.

Wimmer, R.D. \& Dominick, J.R. (2011). Mass media research: An introduction. Canada: Wadsworth. www.tsuuniversity.edu.ng (2016). The registrar's desk.

Yates, D.S., David S. M., Daren S.S (2008) The practice of statistics, $3^{\text {rd }}$ Ed. Freeman. ISBN 978-0-7167-7309-2. 